\title{
Mihály Bulcsú: Mire jó egy szegénytelep a város közepén? - avagy tágabb kontextusok a segítő szemszögéből egy városi szegregátum kapcsán
}

\begin{abstract}
Absztrakt: A cikk a „hírhedt” lakótelep a város központi részén való létét, a városi szociálpolitikában betöltött funkcióját vizsgálja a segítő terepen dolgozó civil szemszögéből. A gans-i funkcionális metódust, illetve az abból fakadó tágabb kontextust hívja magyarázatul, arra a tényre reflektálandó, hogy a szegregált telep szakmai felszámolására két éve még csak terv sincsen, habár a pénz rendelkezésre áll. Vizsgálja, hogy a Telep híre, stigmája hogyan hasznosul a karitatív akciók, müvészeti alkotások, politikai szándékok mentén, ezt hogyan erősíti a COVID-19 okozta speciális helyzet.
\end{abstract}

Kulcsszavak: Hős utca, stigma, funkcionális megközelítés, segítő, közösségi civil nézőpont, média, önkéntesség, karitativitás

\begin{abstract}
The article examines the existence of the famous slum in the city centre, the functions of it in the local social policy from the viewpoint of an NGO field worker. Gans' functionalist method and the wilder context may explain the fact that there is no plan for the liquidation of the settlement since two years, although the money is given. The article analyses how became the stigma of the slum useful by the media, art, charity actions through political aims and how this special situation reinforced by the COVID-19.
\end{abstract}

Key words: Hős street, functionalist method, helper's viewpoint from an NGO, media, volunteering, charity

A cikk célja, hogy reflektáljon a Hős utcai szegénytelep társadalmi szerepére, funkciójára (GANS, 1972), illetve, hogy rávilágítson a megoldás hangsúlyosságára, kihatásaira a segítő szakma szemszögéből. A cím akár lehetne a mitől fontos, mi a jelentősége egy telepnek a város közepén, egyáltalán miért foglalkozzunk vele vagy éppen miért nem. A válaszok azonban álláspontom szerint - ahogy a megnövekedett médiaérdeklődés is mutatja - a szegregátum funkcióiban keresendők.

A „hírhedtnek” nevezett volt szükséglakástelep, ma szegregátum Köbányán a nyolcadik kerülettel határos részen, központi helyen fekszik. Mára megcsappant lakószámmal, de még mindig a városi ,gettókultúra”, az olcsó drogfogyasztás szimbóluma. A Kontúr Egyesület 2011 óta nyújt a telepen kreatív kísérletező pedagógiai- és közösségi alapon nyugvó szociális szolgáltatásokat. Tagjai nem fizetett alkalmazottak, önkéntes alapon, meggyőződésből vannak jelen. Egyesületi tagként ezen tevékenységből fakadó tapasztalataim inspiráltak a cikk megírásában, a segítők nézőpontja, illetve a karitatív segítés mítoszai fontos kiindulópontok lehetnek egy settlement-típusú munka kapcsán. Különösen aktuálisnak gondolom a témát a COVID-19 okozta speciális helyzet fényében. Írásom lényege nem a karitatív akciók, kutatások, önkéntességek, egyéb megjelenések kritikája, hanem azok szakmai szempontú értékelése, látva eredeti tevékenységünk céljait, funkcióit és diszfunkciót. 
Az elmúlt pár hónap eseményei felértékelték a telepet, illetve a telepen élöket segítő civil szervezet járvány alatti tevékenységét. Az Egyesület, nem lévén más eszköze a segítségnyújtásra, kénytelen volt étel- és adománygyüjtéssel pótolni a helyi szociálpolitika hiányosságait, segíteni az alkalmi munkák elmaradása miatt még nehezebb élethelyzetbe került családokat (MIHÁLY, 2020). A járvány időszaka nagyon sok civil szervezet életében hozott változást. Sokan fordultak a karitatív akciók irányába, sokan szembesültek a krízis tényével és az általa okozott károkkal és mivel a hivatalok, szociális intézmények zárva voltak, vagy csak részlegesen müködtek, tulajdonképpen megszünt az értelme a képessé tevés állami / önkormányzati narratívájának. A hiányt pótolni kellett. A depriváltság nyomatékosabban mutatta meg magát, kiélesítve az egyenlőtlenségeket a felvásárlás, tartalékolás, megtakarítás híján meghatározó élménnyé vált (SEN, 1992). A mélyszegénységgel dolgozó civilek sokszor erőn felül teljesítettek (L. RITÓK, 2020), rendkívül jó programokkal, kezdeményezésekkel mutatták a szektor erejét, kreativitását. A legfájóbb azonban az, hogy az ezekről való tudósítás megmaradt helyi szinten (önkormányzati támogatás híján különösen), illetve több helyen nem érte el a sajtó ingerküszöbét, holott a civil szervezetek kreativitása, leleményessége révén született megoldások bemutatása igencsak indokolt lett volna.

A Kontúr Egyesület által segített Hős utcai program igen sokszor szerepelt az országos médiában. Egy kiváló költő versei (ERDÖS, 2020) a telep lakóiról szintén a napokban láttak napvilágot. Számtalan fénykép született, több online beszélgetésre hívtak minket és kértek interjút. A kíváncsiság, híréhség és az elmúlt időszakban megjelent produktumok egyfelől nagyon lényegesek, hiszen szolidalitásról, érdeklődésről tettek tanúbizonyságot. Az önkéntes munka eszközeivel végrehajtott karitatív akciók azt az érzést deklarálták jelesül, hogy „nem hagytak minket magunkra" - ahogy az egyik lakó fogalmazott. Másfelöl akár abszurdnak is tekinthető, hiszen a Hős utcai telepen jelenleg 200 alatti a lakosságszám, lényegesen nem került senki rosszabb helyzetbe, nem történt tartós munka elvesztése. Egy hivatalos segítőszolgálat ügyel hetente a telepen, egy önkormányzat által támogatott alapítvány tart foglalkozásokat és nyújt mentálhigiénés segítséget a Kontúron és a karitatív akciókon kívül, továbbá szerződés szerint egyéb civil szervezetek is nyújtanak szolgáltatást az egész kerületben. Az egyszerü segítő szempontjából sok pénz, nagy összefogás, hírverés egy relatíve kis területen, tartós megoldások, strukturális változások hiátusával.

A továbbiakban nagyvonalakban a szegregátum jellemzőit, a szegregátumot övező történések funkcióit próbálom megvilágítani, a számomra relatíve ellentmondásos történések magyarázatával. HERBERT J. GANS (1992) híres tanulmányában tizenöt funkciót különböztet meg, melyek mindegyike elemezhető és helytálló a Hős utcai szegregátum kapcsán. Ezen írásomban hat funkciót tekintettem hangsúlyosan irányadónak.

- negyedik funkció: munkaalkalmat teremtenek a középosztály számára

- ötödik funkció: intézményi status quo, avagy az érdemtelenség végett a jobbító programok kudarcra vannak ítélve

- hetedik funkció: a társadalmi normák fenntartása

- nyolcadik funkció: politikai átvitel, azaz bünbak funkció

- kilencedik funkció: nyersanyag a szórakoztatóipar számára

- tizedik: a jótékonyság gyakorlása

\section{„Poverty warriors” (Szegényügy harcosai)}

Eredetileg egy szegényellenes program az USA-ban a hatvanas években, mely kritikusai szerint a számos látványos soft elem mellett nem indított el strukturális változásokat (WILSON, 2009). Utal GANS (1972) azokra, akik a szegénynegyedek lakóival a professziójuk, hivatásuk kapcsán 
dolgoznak. Mondván, az is egy funkció, ha őszinték vagyunk. Sőt kettős, hiszen hitelességet jelent és nevelö funkcióval bír. „Fel lehet dolgozni a telepi stigma hátrányait”, az inklúzió (integráció) megvalósítható a szociális munka (jelentsen ez egy politikus szájából bármit is) eszközeivel. Táptalaja a szegénység kultúrájának indokolatlan hangsúlyozásának, (akár annak kritikája a blame the victim) mely azt sugallja, hogy pusztán jószándékkal, strukturális változtatások nélkül, kvázi neveléssel lehet egy mélyszegény lakóközösségben valós, hosszútávú eredményeket elérni. Egy jól sikerül színházi előadás, egy jól megszervezett gyerekprogram (vagy akár annak heti rendszeressége) fontos élmény ugyan, de nem helyettesíti az átfogó programokat, ugyanis a városi szegregátumok hátránya során nem megkerülhetőek a strukturális szempontok (WILSON, 2010).

A Hős utca relációjában sajnos egy egész más „harcról” is szó van. Használhatnám a „roma business"-t, de nem fedné le a lokalitás és a stigmatizáció mindent elhomályosító tényét. A Hős utca, mint problémás terület funkciójában ugyanis arra is szolgál, hogy mint kerületi hírhedt „,negyed” fejlesztési pénzeket vonzzon a kerületbe, kutatásokat, szakértői jelentéseket generáljon, melynek fó elosztói az önkormányzatiság jegyében a kerületi döntéshozók. A telep a tapasztalatok tükrében a választók felé is magyarázat a magas bünözési rátára, a drogfogyasztásra. Nemrégiben a kerület átfogó jelentést készíttetett külső szakemberekkel a droghelyzetről (http1), melynek népszerü politikai interpretációja volt, hogy kerületi szinten nem rosszabb a helyzet, mint a város más részein, tehát, ha a szegregátum nem lenne, akár az egyik legjobb kerület is lehetne, így ezen narratíva akár hivatkozási alap is lehet a intézményfejlesztések elnapolásához. A szegregátum lakói hiába teljesítik az érdemes szegény népszerü kritériumait, hiszen tulajdonosok, munkában megöregedettek, mégis lehetnek a sikertelen programoknak okai és gátja, amikor nem hajlandóak áron alul megszabadulni ingatlanjaiktól. Ugyanakkor lehet hivatkozási alap, bizonyíték más szociális programokban résztvevők számára is, a telep magára hagyottsága, mint egyfajta mérce a relatív fejlödésre, szolgáltatásbővítésre.

A funkció fontosságát jelzi, hogy a telep megszüntetése közel két éve, 2,1 milliárd forinttal megtámogatva, leírt, rendszerezett telepfelszámolási program nélkül történik. A helyi döntéshozók által felkért szakértők nem szociális munkások. Bár kimondhatjuk, hogy a szociális munka szempontjainak mellőzése általános tendencia (BUDAI, 2019), sőt maga a szociális munka egyes vélemények szerint válságát éli (TÖRÖK-MIHÁLY, 2020), mégis sok mindent elárul a folyamatról a terepen jelenlévők teljes folyamatból való kihagyása. Abszurdum számomra azért is, mert az egyetemi képzés hangsúlyos eleme a mélyszegénységben való munka, illetve a projekttervezés, továbbá az érintettek bevonása. Innen nézve jól látszik a kommunikációs cél, a stigma erősítése, illetve a nem megoldásközpontú, az érintettek kihagyásán alapuló diskurzus, mely a funkciót beteljesíti. Azonban az indirekt funkció is teljesül, hiszen beszélnek a telepről, a problémáról, mely a nem felszínes érdeklődő számára több arcát mutatja.

\section{„itt az emberek segítik egymást”}

Az idézet egy riportban hangzott el, melyet egy adományosztásról forgattak és a valóságnál jóval kedvezőbb képet fest a szegregátumról (Http2). A helyzet egy városi szegregátum esetében ennek szöges ellentéte, írja WACQUANT nagyon pontosan egyik tanulmányában: „Az alacsonyrendüség akut érzése, amely áthatja ezeket a hanyatló körzeteket, csak azzal enyhithetö, hogy a helyhez kötödö stigmát egy arctalan, démonizált „,másik”-ra vetítik-az alsó lakókra, a szemközti házban lakó bevándorló családra, az utcabeli „drogos” vagy seftes fiatalokra, vagy a szomszéd háztömbben lakókra." (WACQUANT, 2011: 12). 
Az Egyesület évek óta igen sok mindent tesz, tájékoztat, felmér, nyilatkozik, hogy reális kép alakuljon ki az itt élökről. A helyzet azonban az, hogy ritkán jelenik meg túlzóan pozitív kép a témában. A sajtóorgánumok kétféle képet közvetítenek: 1) a Hös utca, mint bünbarlang és 2) a Hös utca, mint a romantikus egymást segítés színtere, de a valóságban akaratlanul is mindkettővel stigmatizálnak. Nagyon fontos, hogy milyen időszakban készül egy-egy riport, ez előrevetíti a kontextust. (Nyilván színészek nem oszthatnak ételt érdemteleneknek és razziát sem ildomos jóravaló tisztes szegények házában tartani.) A funkció valójában a média történetéhségének kiszolgálása, viszont nem mellékes szál, hogy a riportok hatására relatíve sok új önkéntes, sok érdeklödő figyelt fel a problémára, említeném a WALKER (2014) által is említett tényt, hogy mennél több tapasztalatunk van a szegénységről, annál hajlamosabbak vagyunk azt strukturális, mintsem egyéni indokokkal magyarázni. Éppen ezért a pozitív kép sugárzása felvetheti a városi szegregáció strukturális hibáit, a telepfelszámolás szakmai síkra terelésének szükségességét. Érdekes megfigyelni, hogy a helyi döntéshozók által fenntartott média, mely eddig csak negatív kontextusban beszélt az itt lakókról, utóbbi riportjaiban már nagyon óvatosan fogalmaz és a probléma nagyságát és megoldhatóságát hangsúlyozza.

\section{„levegőben lógó kerítés” (ERDŐS, 2020)}

A mủvészetben való megjelenítése a Hős utcának sajnos szinte nem lehet más, csak a végek és a lecsúszottság bemutatásának eszköze. Álláspontom szerint is elsődleges funkciója mind a rapzene, mind a magaskultúra szintjén annak a bemutatása, hogy ez a kirekesztett világ is Magyarország része. Sajnos kevés mű jut el odáig (az idézett költőnő igen), hogy müveivel arra világítson rá, hogy nem kell, hogy létezzen, hanem az kellene, hogy valaki a felelősségteljes döntéshozás szintjén dolgozzon vele.

Felidézném az esetet, mely tipikusnak is mondható, amikor egy fotómüvésztől kellett elhatárolódnunk, aki a megállapodásunk ellenére a legkirekesztettebb telepi csoport, a jogosulatlan lakáshasználók fényképezését tekintette feladatának, a személyiségi- és gyermeki jogok teljes figyelmen kívül hagyásával. A művész narratívája valamifajta általános krónika, országos helyzetjelentés, de nem állok messze a valóságtól, hogy a gyakorló szakember szempontjából ezt lehet „nyomorpornó”-nak is nevezni.

Mint már említettem, az Egyesület missziójának tekinti a reális kép kialakítását. A lakásfoglalókról kialakult kép meglehetősen sztereotip és messze van a valóságtól. A stigma vidéki kilincsletörőkről szól, akik ellepik a városi szegregátumokat. A valóságban azonban azt találtuk, hogy számarányuk csekély, (10\% alatti), elsősorban tartozás, családon belüli erőszak, pénzbeosztási nehézségek miatt a budapesti lakáspiacról kiszoruló családokról van szó, akik lakhatásukat ideiglenesnek tekintik, de nagy valószínüséggel fizetnek (illegálisan) a lakhatáshoz kapcsolóan.

A funkció sajnos egyértelmü, úgy lehet a mélyszegénységet ábrázolni (öntudatlanul is erősítve a sztereotip képet), hogy nem kell azt a főváros központi részén kívül, sok utazással egybekötve megtenni. Egyébiránt fals, de gyakori ki nem mondott indok, hogy az itt lakóknak érdeke ez a fajta ábrázolás akár személyiségi jogaik mellözésével, hiszen ezzel az ábrázoló felhívja a figyelmet a helyzet komolyságára. Tapasztalatunk szerint azonban csak az érdemtelenség stigmáját erősíti, ráadásul bennem, jelen lévő szociális munkásként komoly etikai kérdéseket is felvet, hogy mennyiben járulok ehhez hozzá (és meddig) passzív szemlélőként.

Gyakori, hogy a telep szemetes állapota illusztrációként jelenik meg egy társadalmi vagy városi probléma kapcsán. A kép szintén csalóka és erősen stigmatizáló. Az Egyesület is sok erőfeszítést tett a lakókörnyezet rendbetételére. Ennek része volt szemétszedési akciók 
szervezése, edukatív plakátok kihelyezése. A lakókkal beszélgetve azonban kiderült, a szemétkérdés a takarítás elmaradása kapcsán kezdett problémássá válni, ugyanis a takarító feladata volt a zacskóban ledobált szemét kivitele a kukába. A takarítás jelenlegi visszaállításával a telep nem szemetes többé. Számításaink szerint a felhalmozott szemét elvitele a járványügyi helyzet miatt többe került, mint a takarító cég, igaz ezen funkció megszünésével jelenleg nem lehet az érdemtelen szegények szemetelési szokásaira hivatkozni. Ugyanakkor a stigmatizált kép akár a chipset fogyasztó, mélyszegénységben élő családok képe erősen eltúlzott és racionális okokra vezethető vissza (MESSING-MOLNÁR, 2011).

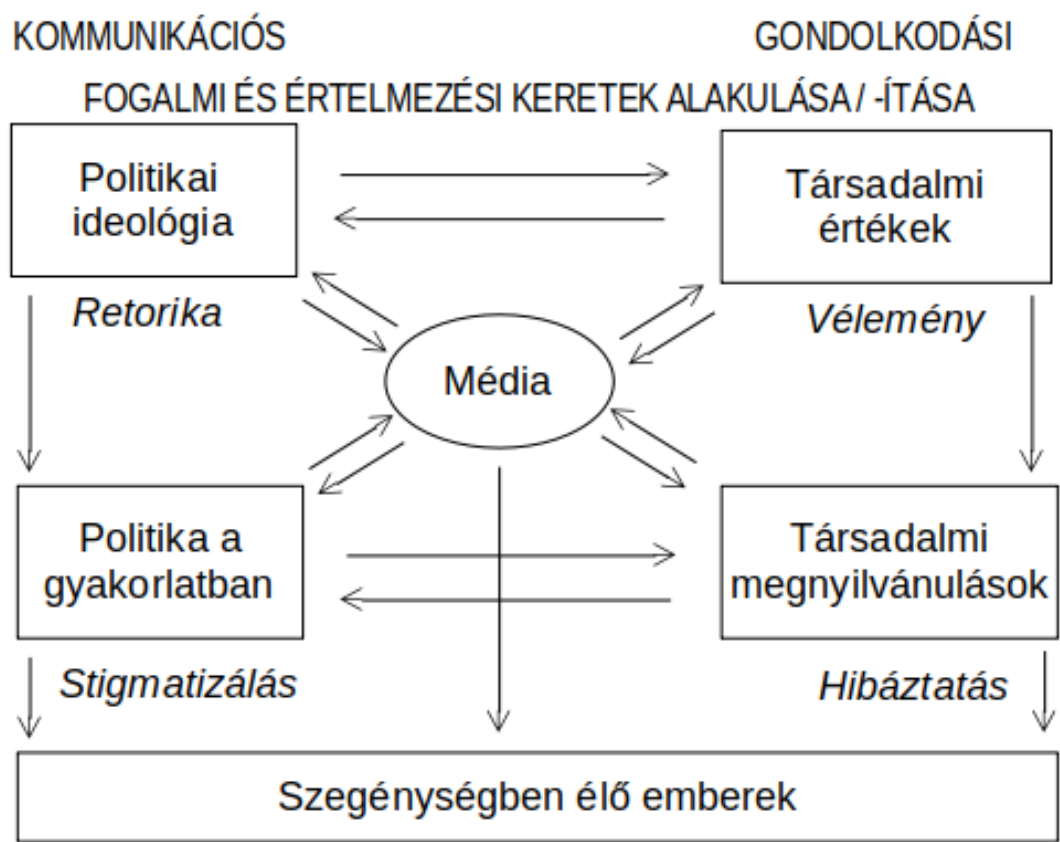

Forrás: WALKER, 2014: p 134

A média szegényekről kialakított képét WALKER (2014) kiválóan érzékelteti ábráján, hogyan stigmatizálja a média szegénységben élőket. Bemutatja a szociális attitűdöket, az abból következő magatartást, véleményt, mely hat a médiára. A médiában megszólaló közszereplők szintén tematizálják a közbeszédet, miközben a média szintén hatással van a szegénységben élők attitüdjeire, de a társadalom attitüdjeire is, és bizonyos mértékig a döntéshozatalra.

Számomra is nehéz elismerni, de beszélnem kell az akadémiai tér funkciójáról is, ugyanis a terepen dolgozók gyakori tapasztalata a kutatásokban való részvételre való felkérés. Nem tudom számba venni hány fókuszcsoportos interjúra, kérdőív kitöltésére kaptunk felkérést, illetve hány szakember kért csak terepen zajló „,idegenvezetést”. Nincs okom feltételezni, hogy az oktatás, a tudomány számára értékes produktumok születtek, de le kell szögeznem, hogy ezek általában egyszeri cselekvések voltak, és a telepen élők helyzetére, a telepi munkára nem voltak hatással.

\section{Önkéntes karitatív akciók}

Funkciójuk, hogy teret nyújtsanak a társadalmi szolidaritásnak. Demonstrálják, hogy a résztvevők nem közönyösek a társadalmi problémák iránt. Diszfunkciója, amikor a közösségi médiában a legjobb szándék ellenére is kéretlen képek és információk jelennek meg. 
Legjobb példája egy édesanya, aki gyermekét egy telepi gyermekkel együtt lefotózva tette ki, demonstrálva, hogy a két gyermek között a különbség a lakókörnyezet. A cél szociális munkás szempontból dicséretes, sőt előítéletet csökkentő. Ugyanakkor számos hátrányos információt oszt meg a szélesebb közönséggel kéretlenül, figyelmen kívül hagyja, hogy a fotón szereplö gyermeknek joga van a privátszférához és valószínüleg szülei nem osztanák meg hátrányos helyzetét, vagyis lakóhelyét a nagyközönséggel. A készítő nemcsak a szegénység kultúrája (AMBRUS, 1988) túlélésének alárendelt jellemzőkről és a szegénység stigmájáról, (WALKER, 2014), de a gyermeki jogokról is megfeledkezik.

Emellett igen fontos funkció a kapcsolat, a segítségnyújtás jó élménye, mely közelebb hoz, illetve a résztvevő hatékonyan tudja befolyásolni környezetét, hogy ne az érdemtelenségben keresse a probléma forrását és megoldását. A karitatív akciók lételeme az edukálás, a figyelem egyszóval nyilvánosság, ugyanakkor tudomásom szerint kevés fellelhető etikai szabályzat található hasonló esetekre (a Gyermekjóléti központokban is alkalmazott GDPR álláspontom szerint nem terjed ki a független karitatív akciókra, esetünkben az illetékesek az akció tényét tudomásul vették). Így ezek kidolgozása szintén a civil segítőkre hárulna. Üdvözlendő a Hintalovon Alapítvány anyaga (http3), mely elsősorban a média számára készült, de iránytüként szolgálhat ezen kontextusban is.

\section{A civilek funkciói}

A Kontúr Egyesület 2011 óta van jelen. Jelenléte bőven több, mint a karitatív akciókban felsorolt funkciók. A gyermekekkel való foglalkozás civil válasz a helyi környezet igazságtalanságaira. A jelenlét, a szociális munka hiányának-pótlásának funkciója ugyanakkor hivatkozási alap a helyi politikában a bajkeverő, „utópista” ellenségkép megalkotására, akikkel szemben felsorakoztatható a tiszta, rendet akaró állampolgár érdeke (mindennek megvan a helye).

A tartós önkéntesség egyénre szabott funkcióival most nem foglalkoznék (társas funkció, társadalmi felelősségvállalás stb). Inkább az Egyesület harcát emelném ki, minthogy deklarált célja, hogy a szegregátum megszüntetése - a szakértői terv szerint - az érintettek bevonásával történjen. A funkció azonban az Egyesület tagjai szerint túl kell mutasson a lokalitás szintjén, ugyanis nem minden stigmatizált telep van a város szívében, nem minden szergregátumot segít aktivizmus. A megnövekedett figyelem kedvezőbb pozíciót jelent, modellként, figyelemfelhívásként is szolgál, bizonyítva (eredménytől függően) a civilség, a független terepi munka erejét.

\section{Milyen funkciói lehetnek (illetve kellene, hogy legyenek) egy szegénytelepnek?}

Talán közhely, de sokszor elfelejtett közhely, hogy „, a szociálpolitika nem teóriáknak az életre való erőszakolásával dolgozik, hanem realitásokkal (...)” (HILSCHLER,1928: 41). A városi szegregátumok funkcióit tekintve adok-kapok alapon, kiváló terepei lehetnének a reflektív gyakorlati munkának. A civil szektorban dolgozók emberjogi megközelítése gyakran közelebb is áll a jelenleg divatos szociális munka irányzatokhoz, módszerekhez, ráadásul a náluk gyakorlatot szerzők tapasztalatom (és a logika) szerint másképp viszonyulnak (képessé tevés alapján) a kliensközpontúság vagy a kényszerített ügyfél meghatározottságához. Mentoráláson, önkéntes segítő tevékenységen keresztül jellemzően azonban ezek a projektek hosszabb távú elköteleződést kívánnának, melyeknek motivációihoz, módszereihez a gyakorlati oktatás, a nagyobb képzési központok, alapítványok adhatnának segítséget. A settlementnek, azaz tartós jelenléten alapuló módszernek a szociális munkában igenis helye van (HEGYESI, 1990). A 
szakmai érdekképviseletet ellátó szervezeteknek, kutatóknak funkciója kellene, hogy legyen a problémafeltárás, javaslatok nyomatékosítása, felhívva a figyelmet az érintettek bevonása nélküli (BAKOSI, 2013) fejlesztések veszélyes zsákutcájára.

\section{Összegzés}

Összegezve a problémát, a GANS szellemében (1972) felsorolt funkciókkal, a legfőbb probléma segítő szemszögből nem a meglétük (nyilván jobb lenne, ha nem lennének), hanem ha egy cselekvés, történés kapcsán figyelmen kívül hagyjuk őket, illetve ha azt gondoljuk, hogy egy pozitív funkció betöltése feltétlen pozitív hatással van a segítettjeink életére.

A karitatív akciók során meg kell határozzuk, hogy mely edukatív funkció szolgálja a társadalmi integráció érdekeit, mely adományosztás kontraproduktív, illetve fontos nemet mondani azon felkérésekre, melyek a segítő folyamattól veszik el az időt és energiát. Civilként jelenlévőként nyomatékosítani szükséges (akkor is, ha kisebb kört ér el) a nem megfelelö riportok káros voltát. Szervezeti szinten pedig, bár idő- és néha költségigényes, ahol lehet, ott ragaszkodni kell az önkéntesek, tudósítók, müvészek, kutatók etikai felvilágosításához. Meggyőződésem, hogy érdemes egy-egy terepi munka funkcióit, kontextusát vizsgálni.

Időigényes és konfliktusokkal teli hosszabb távú programokban, elköteleződésben és nem egyszeri riportokban, akciókban gondolkodni, de a kirekesztés elleni segítői tevékenység csak az emberi jogok mentén, a szolidalitás dimenziójában értelmezhető a tágabb környezet érzékenyítésével, felvilágosításával párhuzamosan.

\section{Irodalom}

AMBRUS P. (2010): Dzsumbuj. Magvető Kiadó, Budapest.

BAKOSI T. (2013): Gondolatok a szegénységben élők érdekérvényesítő képességének javításáról. MACSGYOE, Budapest.

http://www.macsgyoe.hu/downloads/szakmai_anyagok/bakositamasszegenyseg.pdf

Látogatva: 2020.09.29.)

BUDAI I. (2019): Dinamikus egyensúlyok víziója és lehetősége a szociálismunkás-képzésben I., Esély 3, 101-113.

ERDŐS V. (2020): Hősöm. Magvető Kiadó, Budapest.

GANS, J.H. (1972): The Positive Functions of Poverty. American Journal of Sociology, 2. 275 289.

GANS, J.H (1992): Mire szolgálnak az érdemtelen szegények. Esély, 3. 3-17.

HEGYESI G. (1990): Egy szociálpolitikus életmüve. Esély, 3. 21-30.

HILSCHLER R. (1990): A szociálpolitika lényege és feladatai. Esély, 3. 40-44.

L RITÓK N (2020): Összefogás vagy széthúzás - Civilek a járvány idején. https://szocio.atlatszo.hu/2020/06/05/osszefogas-vagy-szethuzas-civilek-a-jarvany-idejen/

(Látogatva: 2020.09.29.)

MESSING V., MOLNÁR E. (2011): Válaszok a pénztelenségre: szegény cigány és nem cigány családok megélhetési stratégiái. Esély, 1. 53-80.

MIHÁLY B. (2020): Adományosztásos tudathasadás. KCM blog. https://toledhallottam.hu/index.php/civilk/civil-hirek/elte-kcm (Látogatva: 2020.09.29.)

SEN, A (1992): A relatív szegény. Esély, 3. 3-16. 
TÖRÖK ZS. S., MIHÁLY B. (2019): A szociális munka válsága a lakhatási válság szemszögéből. Párbeszéd: Szociális Munka folyóirat, 3. https://ojs.lib.unideb.hu/parbeszed/article/view/4709/4463 (Látogatva: 2020.09.29.)

WACQUANT, L. (2011): Lakóhely szerinti megbélyegzés a fejlett marginalitás korában. Fordulat, 1. 12-18.

WALKER, R. (2014): The Shame off Poverty. Oxford University Press, Oxford.

WILSON, J. W (2009): More than just race: Being Black and Poor in the Inner City. Norton Company, New York.

\section{Internetes források}

http:// 1. www.magyarhirlap.hu/belfold/20190625-fejleszteni-kell-a-drogprevenciot (Idézet a Magyar Hírlakból; Látogatva: 2020.09.29.)

http:// 2. https://rtl.hu/rtlklub/fokusz/szabo-gyozo-es-molnar-aron-csapata-mar-tobb-ezermeleg-etelt-osztott-ki (Idézet az RTL Klub Fókusz c. müsorából; Látogatva: 2020.09.29.)

http:// 3. https://hintalovon.hu/ (Hinatalon Alapítvány; Látogatva: 2020.09.29.) 